\title{
Heavy metals effect on breast cancer progression
}

\author{
A. Romaniuk ${ }^{1}$, M. Lyndin ${ }^{1}$, V. Sikora ${ }^{{ }^{*}}$, Y. Lyndina ${ }^{2}$, S. Romaniuk ${ }^{3}$ and K. Sikora ${ }^{4}$
}

\begin{abstract}
Background: Breast cancer is the most frequent localization of malignant process in American women and women of European countries. To date it is not possible to control the morbidity growth due to lack of effective ways of primary prevention. Comparing the incidence of breast cancer in developed countries with the countries of Asia and Africa, there is the fact of population predominance lesion in more urbanized countries. This suggests that the environment along with other factors, occupies a significant place in the initiation and progression of breast neoplasia. The impressive rates of industrial development led to the pollution of soil, surface water and, as a consequence, food by heavy metal salts.

The purposes of this paper are as follows: the chemical composition determination of neoplastic breast tissue, evaluation of the DNA methylation level, study of prognostic-important receptors expression in the breast cancer cells, establishing linkages between all the derived indicators.

Methods: In our study we used the following methods: studying of the chemical composition of breast cancer tissue by atomic absorption spectrophotometry and energy-dispersion spectrometer; immunohistochemical study of ER, PR, HER2/neu, p53, Ki-67, E-cadherin and MGMT receptors; DNA extraction and investigation by oscillating infrared spectroscopy method.

Results: The total amount of heavy metals in breast cancer tissue ranged from $51.21 \times 10^{-3}$ to $84.86 \times 10^{-3} \mathrm{\mu g} / \mathrm{kg}$. We have got the following results: the growth of heavy metals in neoplastic tissue is accompanied with the increase of HER2/neu, p53, Ki-67, MGMT expression and decrease of ER and PR expression. The increment of pathological DNA methylation is accompanied with the increasing amount of heavy metals in tumor tissue.

Conclusions: Heavy metals through different pathogenetic links stimulate the progression of breast cancer and reduce its sensitivity to treatment. DNA of tumor tissue has a different level of methylation which changes with the amount of heavy metals in cancer cells. This is displayed on the synthesis of prognostically important receptors in neoplastic tissue.
\end{abstract}

Keywords: Breast cancer, Heavy metals, DNA methylation, Receptors

\section{Background}

Breast cancer $(\mathrm{BC})$ is the most frequent localization of malignant process in American women and women of European countries [1]. In Ukraine, this pathology is found in 16,000 women each year (the incidence is 64.5 per 100,000 women) [2]. Nowadays it isn't possible to control the growth of morbidity due to lack of effective ways of primary prevention. Comparing the incidence of $\mathrm{BC}$ in developed countries with the countries of Asia

\footnotetext{
* Correspondence: v.sikora@med.sumdu.edu.ua

${ }^{1}$ Department of pathology, Sumy State University, st. Privokzalnaya, 31, Sumy

Postal code 40022, Ukraine

Full list of author information is available at the end of the article
}

and Africa, unfortunately, there is the fact of predominance lesion of population in more urbanized countries [3]. Thus, this suggests that the environment along with other factors, occupies a significant place in both the initiation and progression of breast neoplasia [4]. The impressive rates of industrial development led to the pollution of soil, surface water and, as a consequence, food by heavy metal salts.

During investigation of the environment in Ukraine it was found that the amount of iron, chromium, copper, nickel, lead and zinc salts in the ground were increased [5]. 
It is known that the carcinogenic effect of heavy metals (HM) is realized through the mechanisms of DNA structure breach and suppression of antioxidant protection [6, 7]. Furthermore, there is information about the possibility of heavy metals influence on the expression of prognostic-important receptors in $\mathrm{BC}$ tissue $[8,9]$. Previously, it was found that breast tissue (unaltered and affected by tumor process) can accumulate heavy metals that influence on the DNA fragmentation level and tumor cells survival [10].

It is generally known that the most important receptors in $\mathrm{BC}$ tissue are the estrogen receptor (ER), progesterone receptor (PR), human epidermal growth factor receptor 2 (HER2/neu), Ki-67 and p53. Moreover, ER and $\mathrm{PR}$ status of $\mathrm{BC}$ is recognized as one of the most powerful prognostic markers. If the tumor belongs to steroid-positive variant, it is managed and controlled by anti-estrogen drugs [11]. Contrary to this, the expression of HER2/neu indicates the tumor resistance to chemotherapy, including tamoxifen, aggressiveness of cancer [12]. The degree of differentiation and malignancy of $\mathrm{BC}$ is largely determined by proliferative activity of tumor cells. Study of Ki-67 protein that is expressed in all cells that came from $G_{0}$-phase allows to determine "hidden" proliferative potential of neoplasia and to evaluate its malignancy extent [13]. Pathological p53 presents in $18 \%-25 \%$ of BC cases. Functional inactivation of wild type (wt) p53 and synthesis of mutant type (mt) p53 are associated with early recurrences, poorer course and resistance to chemotherapy [14].

DNA methylation, the accession of methyl groups to the nitrogenous bases, is a modification of DNA without changing its nucleotide sequence [15]. "Silence" of tumor suppressor genes by DNA methylation is a powerful molecular mechanism by which DNA methylation can initiate cancer. It also substantiates therapy that aims to inhibit DNA methylation, and reactivation of blocked tumor suppressor genes [16]. It has been described a significant correlation between DNA methylation and expression of BC key genes such as MYC, TERT, TP63 and others [17]. However, hypomethylation is no less important because the critical genes of growth and metastasis are hypomethylated in cancer tissue [18].

O6-methyguanine-DNA methyltransferase (MGMT), with its gene being located on the chromosome 10, eliminates DNA damage by alkylating agents, removing their cytotoxic effect [19]. Afferent protein sequence is combined with damaged nucleic acid and without changing DNA structure takes alkyl residue [20]. Nevertheless, inactivated MGMT may enter into relationship with receptors for steroid hormones, inhibiting their function, thereby blocking the signal transmission for cell division [21]. There is information about inhibitory effect of heavy metal salts on MGMT activity. It has been shown that the expression of MGMT in tumor cells can be increased, demonstrating $\mathrm{BC}$ resistance against chemotherapy [22], and can be decreased (due to methylation of MGMT promoter), providing the possibility of "cancer" cells enter into apoptosis [23]. MGMT-positive status of the tissue is correlated with the identification of luminal molecular types of $\mathrm{BC}$ and low cell proliferative activity [24]. Considering this, it was proposed to examine the expression of MGMT as a separate prognostic factor of breast malignancy [23].

In summary we can say that nowadays the question remains open concerning the relationship between the tumor chemical composition, DNA methylation and expression of prognostic receptors of $\mathrm{BC}$ tissue.

The objectives of this paper are as follows: the chemical composition determination of neoplastic breast tissue, evaluation of the DNA methylation level, study of prognostic-important receptors expression in the $\mathrm{BC}$ cells, establishing linkages between all the derived indicators.

\section{Methods}

The tissue ( 40 samples of $\mathrm{BC}$ tissue and 20 samples of intact breast tissue) received during the postoperative biopsy was kept in the refrigerator. It became the subject of the further investigation after the establishing of the histological diagnosis. The diagnosis of invasive ductal carcinoma (IDC) with varying of malignancy degree (by Scarff-Bloom-Richardson) was found after the standard hematoxylin eosin staining of prepared slices.

\section{Studying of the chemical composition of BC tissue}

Tissue samples for atomic absorption spectrophotometry were weighed with an accuracy of $0.001 \mathrm{~g}$. Then they were burned in a muffle furnace at a temperature $450{ }^{\circ} \mathrm{C}$ for removing the organic matrix. The resulting ash was dissolved in a mixture of hydrochloric $(2 \mathrm{ml})$ and nitric $(1 \mathrm{ml})$ acids. The resulting solution was analyzed by C115-01 spectrophotometer with flame and electrothermal atomiser. Each microelement (increased amount of which is inherent for the Ukraine) content was measured at a specific wavelength: $\mathrm{Zn}-213.9 \mathrm{~nm}, \mathrm{Cu}-$ $324.7 \mathrm{~nm}, \mathrm{~Pb}-283.3 \mathrm{~nm}, \mathrm{Cr}-357.9 \mathrm{~nm}, \mathrm{Fe}-$ $248.3 \mathrm{~nm}$ and $\mathrm{Ni}-240.7 \mathrm{~nm}$. Measurements and calculations were performed by «AAS-SPECTR» program.

Paraffin sections (of $5 \mu \mathrm{m}$ thickness) for energy dispersive spectrometry were subjected to dewaxing and applied on spectral pure graphite rods. Chemical composition was studied by means of the scanning electron microscope with energy-dispersion spectrometer [25]. Digital images of the specimen and the indicators of microelements content were identified by Magellanes and VCU software. 
Table 1 Antibody for immunohistochemical reaction («Thermo Fisher Scientific», USA)

\begin{tabular}{lllll}
\hline Antibody & Host & Clone & Dilution & Cellular localization \\
\hline ERa & Rabbit & SP1 & $1: 200$ & Nuclear \\
PR & Rabbit & YR85 & $1: 150$ & Nuclear \\
HER2/neu & Rabbit & SP3 & $1: 100$ & Membrane \\
p53 & Mouse & SP5 & $1: 100$ & Nuclear \\
Ki-67 & Rabbit & SP6 & $1: 100$ & Nuclear \\
MGMT & Mouse & MT3.1 & $1: 50$ & Cytoplasmic and nuclear \\
E-cadherin & Rabbit & 67A4 & $1: 100$ & Membrane \\
\hline
\end{tabular}

\section{Immunohistochemical study}

The material for the immunohistochemical reaction was fixed in $10 \%$ neutral formalin for $24 \mathrm{~h}$, after that paraffin blocks were made of it. Then sections of 3-4 $\mu \mathrm{m}$ thickness were made and they were subjected to the standard process of dehydration in xylol and alcohols of rising concentration. Immunohistochemical reaction consisted of 2 stages. During the first stage the incubation with primary rabbit antibodies («Thermo Fisher Scientific», USA) in different dilutions in tissue sections took place (Table 1). Then we conducted the receptor visualization using detection systems «UltraVision Quanto Detection System HRP DAB Chromogen» («Thermo Fisher Scientific», USA). We visualized the cell structural components using diaminobenzidine, which painted them in a brown color. We have performed immunohistochemical reaction with E-cadherin for the purpose of the differential diagnosis between high degree malignant invasive lobular carcinoma and IDC. The positive reaction took place only in IDC.

\section{DNA extraction and investigation}

DNA was extracted from the tissue using a lysis buffer which consisted of $30 \mathrm{mM}$ hydroxymethylaminomethane, $10 \mathrm{mM}$ ethylenediamine-tetraacetic acid, 1\% sodium dodecyl sulfate and $5 \mathrm{mg}$ proteinase $\mathrm{K}$
( $\mathrm{pH}$ 8.0). DNA was purified with phenol-chloroform extraction and the following precipitation in absolute ethanol.

DNA methylation level was determined at the Institute for Single Crystals, National Academy of Sciences (Ukraine) using the oscillating infrared spectroscopy method. An obligatory condition was the deprivation of samples of auxiliary substances (absolute ethanol, chloroform, phenol and others) that were used for DNA extraction, and that could overcharge DNA spectrum. Obtained DNA product was triturated with $\mathrm{KBr}$ and placed into tablets for infrared spectroscopy on the SpectrumOne spectrometer. Spectrum analysis was performed by OridionVersion8 program.

\section{Statistical analysis of the results}

Mathematical calculations were done using Microsoft Excel 2010 with 12.0.5 Attestat option. We have found such indicators as chi-squared Pearson's test, Pearson's correlation coefficient (with statistical significance $p<0.05)$.

\section{Results}

The invasive ductal carcinoma is characterized by the formation of nests, clusters and trabeculas, though some tumors are characterized by solid growth with a small amount of stroma. Some part of the tumor has clear tubular structures with lumen in the center. The cells are quite variable in structure. The cytoplasm is often broad and eosinophilic. The nuclei are round, monomorphic or with polymorphism and well-visible nucleoli. The mitotic activity varies greatly - from full absence to 10-20 or more in one field of view (Fig. 1).

Using atomic absorption spectrophotometry of IDC tissue it has been found that the content of iron was from $38.46 \times 10^{-3}$ to $69.63 \times 10^{-3} \mu \mathrm{g} / \mathrm{kg}$ (average $59.73 \times 10^{-3} \mu \mathrm{g} /$ $\mathrm{kg}$ ), copper - from $2.8 \times 10^{-3}$ to $9.11 \times 10^{-3} \mu \mathrm{g} / \mathrm{kg}$ (average $5.66 \times 10^{-3} \mu \mathrm{g} / \mathrm{kg}$ ), chromium - from 0 to $6.1 \times 10^{-3} \mu \mathrm{g} / \mathrm{kg}$ (average $2.41 \times 10^{-3} \mu \mathrm{g} / \mathrm{kg}$ ), zinc - from $1.89 \times 10^{-3}$ to



Fig. 1 Invasive ductal carcinoma of varying degrees of malignancy by Scarff-Bloom-Richardson. a - well-differentiated carcinoma, $\mathbf{b}$ - moderately differentiated carcinoma, c - poorly differentiated carcinoma. Staining with hematoxylin and eosin. Magnification $\times 100$ 
$6.4 \times 10^{-3} \mu \mathrm{g} / \mathrm{kg}$ (average $4.25 \times 10^{-3} \mu \mathrm{g} / \mathrm{kg}$ ), lead - from 0 to $0.6 \times 10^{-3} \mu \mathrm{g} / \mathrm{kg}$ (average $0.11 \times 10^{-3} \mu \mathrm{g} / \mathrm{kg}$ ) and nickel - from $0.08 \times 10^{-3}$ to $0.52 \times 10^{-3} \mu \mathrm{gg} / \mathrm{kg}$ (average $0.3 \times 10^{-}$ ${ }^{3} \mu \mathrm{g} / \mathrm{kg}$ ). The total amount of HM ranged from $51.21 \times$ $10^{-3}$ to $84.86 \times 10^{-3} \mu \mathrm{g} / \mathrm{kg}$ (average $72.44 \times 10^{-3} \mu \mathrm{g} / \mathrm{kg}$ ). In near located intact breast tissue these levels were much lower: iron on the average $34,26 \times 10^{-3} \mu \mathrm{g} / \mathrm{kg}$, copper $2.73 \times 10^{-3} \mu \mathrm{g} / \mathrm{kg}$, chromium $-0.92 \times 10^{-3} \mu \mathrm{g} / \mathrm{kg}$, zinc $1.67 \times 10^{-3} \mu \mathrm{g} / \mathrm{kg}$, lead $-0.04 \times 10^{-3} \mu \mathrm{g} / \mathrm{kg}$ and nickel $0.1 \times 10^{-3} \mu \mathrm{g} / \mathrm{kg}$ (Table 2).

In order to determine the spatial features of $\mathrm{HM}$ localization in "cancer" tissue we studied the chemical composition of IDC by energy dispersion method on scanning electron microscope. This process took place in two functional modes: local scanning of the sample surface at different zoom levels and focal scanning, considering trace-element composition of parenchymal and stromal components of BC tissue (Fig. 2). Such macroelements as calcium, phosphorus, potassium, sulfur and sodium dominated in neoplastic tissue. Such heavy metals as zinc, iron, copper, chromium, nickel and lead are encountered in different proportions among other microelements. We have found that HM accumulated more in the parenchymal component of tumor tissue $(p<0.05)$. Comparing the data of two studies on the detection of the chemical composition we've got identical results - if the concentration of $\mathrm{HM}$ in a gram of tumor was increased then the percentage content also grew that have been obtained using energydispersive method of study $(\mathrm{p}<0.05)$. The relationship $(r$ $=0.62, p<0.01$ ) between the HM accumulation in the foci of neoplasia and the degree of malignancy of $\mathrm{BC}$ has been established.

Immunohistochemical analysis has revealed different variants of receptors expression. 63\% of tumors were ER-positive that was evaluated according to D.C.Allred recommendations. In $50 \%$ of cases we have revealed the presence of PR. Investigating the presence of HER2/neu receptors we have found that 12 samples were receptor positive. Studying the expression of Ki-67 receptor we have found that IDC tissue in $87.5 \%$ of cases possessed varying degree of proliferative activity. The presence of mutated proapoptotic protein p53 (mt p53) has been found in $37.5 \%$ of samples of BC (the possibility to identify wt p53 protein was absent due to the short time of its existence and its below a threshold level - this number is impossible to detect by immunohistochemical studies). The examples of receptor-positive variants of $\mathrm{BC}$ tissues are shown in Fig. 3. The results of statistical data processing of immunohistochemical studies have found that in our research the correlative connections were as follows: the positive correlative connections between ER and PR $(r=0.85, p<0.01)$, p53 and Ki-67 $(r=$ $0.55, \mathrm{p}<0.01)$; the negative correlative connections between ER and HER2/neu $(r=-0.56, \mathrm{p}<0.01), \mathrm{PR}$ and
Table 2 The content of HM in cancerous and healthy breast tissue $\left(\times 10^{-3} \mathrm{\mu g} / \mathrm{kg}\right)$

\begin{tabular}{|c|c|c|c|c|c|c|c|}
\hline & Iron & Copper & Zinc & Lead & Chromium & Nickel & Total \\
\hline 1. & 41.36 & 4.23 & 3.74 & 0.16 & 1.46 & 0.26 & 51.21 \\
\hline 2. & 44.17 & 3.42 & 4.17 & 0.09 & 0.72 & 0.34 & 52.91 \\
\hline 3. & 38.46 & 4.8 & 4.1 & 0.18 & 5.1 & 0.42 & 53.06 \\
\hline 4. & 39.65 & 4.71 & 5.11 & 0.14 & 3.41 & 0.23 & 53.25 \\
\hline 5. & 51.27 & 5.57 & 1.89 & 0.14 & 1.32 & 0.28 & 60.47 \\
\hline 6. & 52.26 & 4.32 & 4.08 & 0.01 & 0.65 & 0.34 & 61.66 \\
\hline 7. & 49.38 & 6.56 & 3.35 & 0.15 & 2.46 & 0.29 & 62.19 \\
\hline 8. & 52.44 & 4.89 & 3.29 & 0 & 1.78 & 0.28 & 62.68 \\
\hline 9. & 47.81 & 6.32 & 3.89 & 0.07 & 4.53 & 0.28 & 62.9 \\
\hline 10. & 53.48 & 5.82 & 3.23 & 0.18 & 1.56 & 0.32 & 64.59 \\
\hline 11. & 52.4 & 5.61 & 5.09 & 0.14 & 1.78 & 0.29 & 65.31 \\
\hline 12. & 56.54 & 3.56 & 3.54 & 0.01 & 2.12 & 0.3 & 66.07 \\
\hline 13. & 55.84 & 6.18 & 3.65 & 0 & 2.11 & 0.25 & 68.03 \\
\hline 14. & 54.63 & 6.19 & 5.33 & 0.16 & 3.1 & 0.35 & 69.76 \\
\hline 15. & 61.41 & 5.13 & 2.93 & 0.08 & 0.78 & 0.26 & 70.59 \\
\hline 16. & 60.87 & 3.65 & 4.48 & 0.19 & 2.23 & 0.28 & 71.7 \\
\hline 17. & 62.62 & 2.8 & 4.1 & 0.09 & 2.47 & 0.34 & 72.42 \\
\hline 18. & 61.89 & 3.69 & 4.44 & 0.16 & 2.32 & 0.34 & 72.84 \\
\hline 19. & 60.55 & 6.21 & 3.45 & 0.06 & 2.51 & 0.32 & 73.1 \\
\hline 20. & 68.39 & 4.81 & 2.8 & 0.09 & 0 & 0.16 & 76.25 \\
\hline 21. & 64.33 & 7.25 & 3.36 & 0 & 1.52 & 0.29 & 76.75 \\
\hline 22. & 64.48 & 5.25 & 4.88 & 0.04 & 2.86 & 0.36 & 77.87 \\
\hline 23. & 65.86 & 4.23 & 3.86 & 0.03 & 3.62 & 0.28 & 77.88 \\
\hline 24. & 63.81 & 5.26 & 5.23 & 0.11 & 3.51 & 0.27 & 78.19 \\
\hline 25. & 62.57 & 8.11 & 5.69 & 0.03 & 1.85 & 0.35 & 78.6 \\
\hline 26. & 63.23 & 8.66 & 5.78 & 0.14 & 1.69 & 0.08 & 79.58 \\
\hline 27. & 65.59 & 6.36 & 4.77 & 0.19 & 2.45 & 0.26 & 79.62 \\
\hline 28. & 65.21 & 7.63 & 4.11 & 0 & 2.56 & 0.28 & 79.79 \\
\hline 29. & 69.63 & 5.77 & 2.75 & 0.14 & 1.32 & 0.28 & 79.89 \\
\hline 30. & 68.12 & 5.11 & 2.84 & 0.11 & 3.54 & 0.28 & 80 \\
\hline 31. & 67.54 & 2.99 & 5.66 & 0.08 & 3.66 & 0.28 & 80.21 \\
\hline 32. & 66.25 & 7.36 & 4.28 & 0.14 & 2.36 & 0.32 & 80.71 \\
\hline 33. & 68.33 & 7.68 & 3.65 & 0.11 & 0.92 & 0.33 & 81.02 \\
\hline 34. & 68.87 & 5.12 & 4.26 & 0.08 & 2.66 & 0.3 & 81.29 \\
\hline 35. & 68.65 & 5.36 & 3.96 & 0 & 3.15 & 0.29 & 81.41 \\
\hline 36. & 67.2 & 5.17 & 6.11 & 0.12 & 2.63 & 0.3 & 81.53 \\
\hline 37. & 67.25 & 6.29 & 4.85 & 0.06 & 3.6 & 0.25 & 82.3 \\
\hline 38. & 66.65 & 8.62 & 4.42 & 0.16 & 2.24 & 0.29 & 82.38 \\
\hline 39. & 68.11 & 6.59 & 6.38 & 0 & 1.86 & 0.35 & 83.29 \\
\hline 40. & 62.13 & 9.11 & 6.4 & 0.6 & 6.1 & 0.52 & 84.86 \\
\hline Minimum value & 38.46 & 2.8 & 1.89 & 0 & 0 & 0.08 & 51.21 \\
\hline Maximum value & 69.63 & 9.11 & 6.4 & 0.6 & 6.1 & 0.52 & 84.86 \\
\hline Average value & 59.73 & 5.66 & 4.25 & 0.11 & 2.41 & 0.3 & 72.44 \\
\hline $\begin{array}{l}\text { Average value in } \\
\text { healthy breast tissue }\end{array}$ & 34.26 & 2.73 & 1.67 & 0.04 & 0.92 & 0.1 & 72 \\
\hline
\end{tabular}



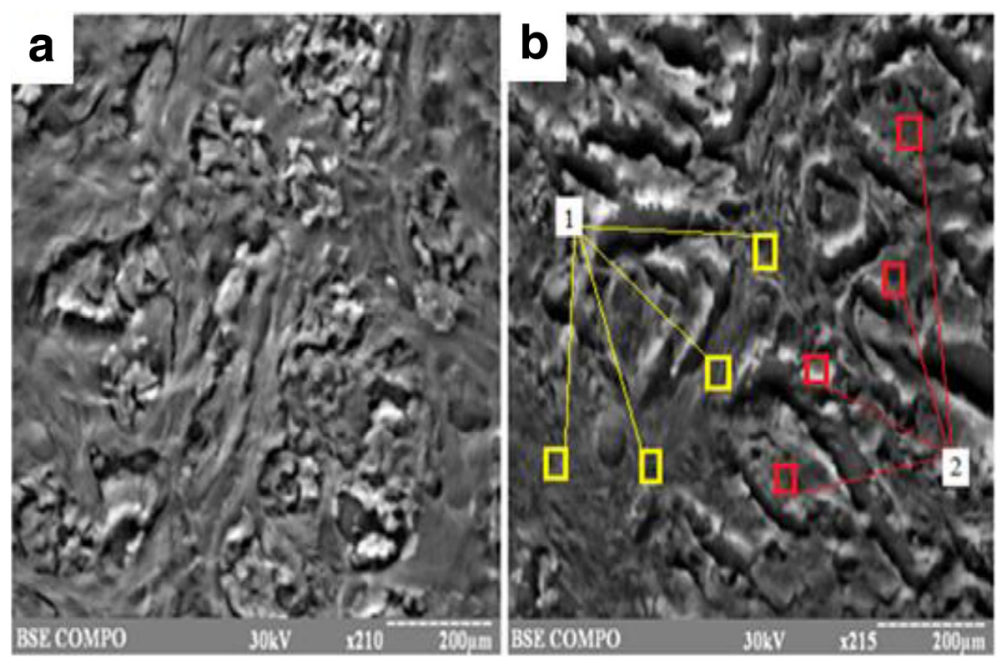

Fig. 2 The scanning images of IDC tissue. a - local scanning of the sample surface (x210), b - focal scanning (x215): 1 - stromal component of tissue, 2 - parenchymal component of tissue

HER2/neu $(r=-0.58, \mathrm{p}<0.01)$, ER and Ki-67 $(r=-0.37$, $p<0.05)$, PR and Ki-67 $(r=-0.33, \mathrm{p}<0.05)$.

The patterns of MGMT expression, according to the recommendations of the manufacturer of the antibodies, were cytoplasm and nucleus (Fig. 4). In our studies it has been received more pronounced nuclear localization of MGMT. This confirms the basic function of MGMT, which carries an alkyl residue (methyl-, ethyl-, n-propiland others) from $\mathrm{O}^{6}$ position of guanine on its 145th active site which respectively is localized in the nucleus of "cancer" cells. We have not established the cases in which pattern of expression was only cytoplasm. During research we have revealed the following results: 17 cases (42.5\%) of IDC were MGMT-positive and 23 samples (57.5\%) - MGMT-negative. Cytoplasmic expression of
MGMT has been found in almost 30\% of BC cases. Investigating the combination of MGMT and ER expression we have revealed an interesting pattern - during the increase of MGMT expression the level of steroid hormone receptors decreased $(r=-0.5, p<0.01)$.

According to the results of spectroscopy, the range of DNA fluctuations is located within $400-4000 \mathrm{~cm}^{-1}$. We conventionally divided obtained infrared DNA spectra into three areas: the first area corresponded to the spectrum of nitrogenous bases fluctuations (4000$2000 \mathrm{~cm}^{-1}$ ), the second - the fluctuations of deoxyribose $\mathrm{CH}_{2}$-groups (1700-1500 $\mathrm{cm}^{-1}$ ) and the third - the fluctuations of the deoxyribose and phosphate groups in the skeleton of DNA molecules $\left(1300-1000 \mathrm{~cm}^{-1}\right)$. The spectra were divided into weak $\leq 5 \%$, average $-5-20 \%$ and
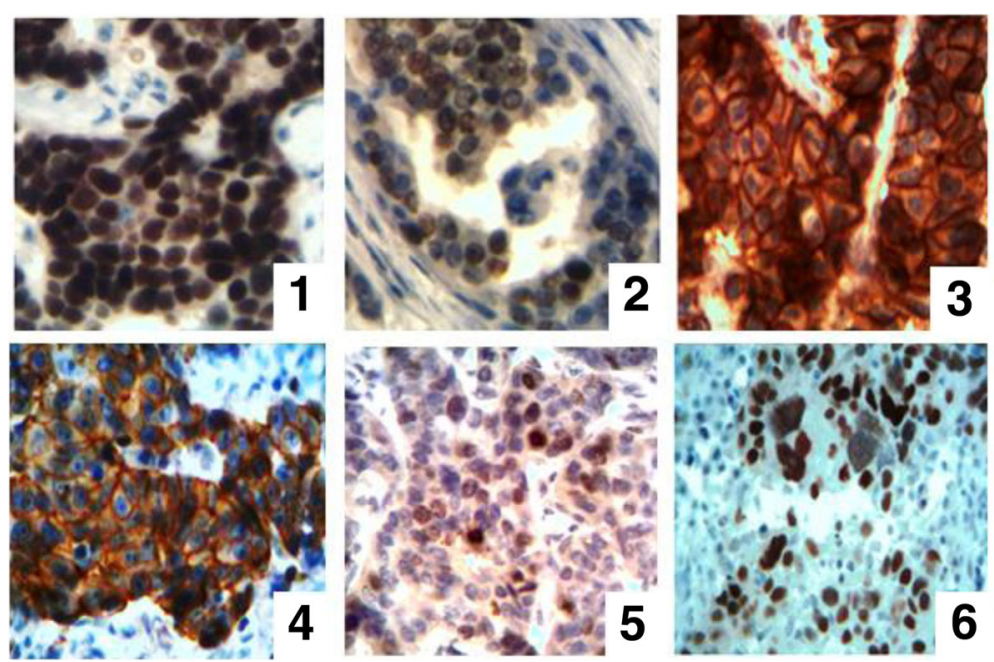

Fig. 3 The immunohistochemical study of BC tissue. $\mathbf{1}$ - ER, $\mathbf{2}-\mathrm{PR}, \mathbf{3}-\mathrm{HER} 2 /$ neu, $\mathbf{4}-\mathrm{E}$-cadherin, $\mathbf{5}$ - Ki-67, $\mathbf{6}$ - p53. Magnification ×400 


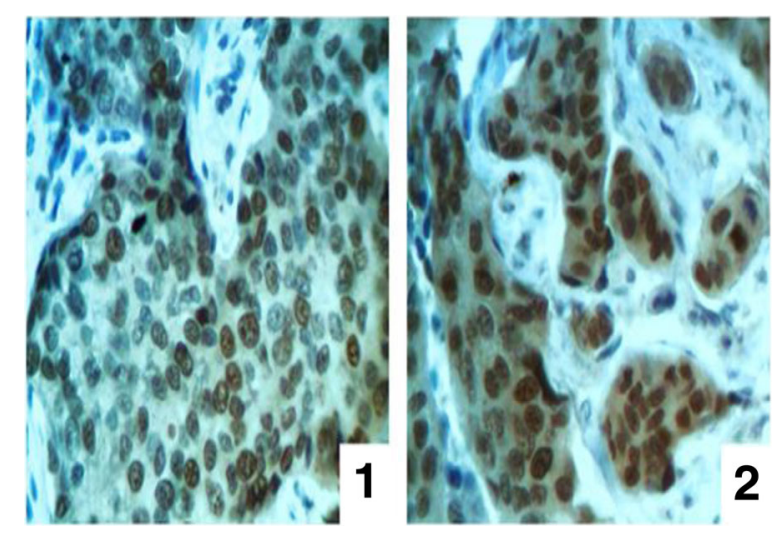

Fig. 4 The immunohistochemical study of MGMT. 1 - IDC tissue with nuclear localization of the enzyme, $\mathbf{2}$ - IDC tissue with nuclear and cytoplasmic localization of the enzyme. Magnification $\times 400$

strong $-\geq 20 \%$, depending on the intensity of infrared absorption. The attention was also paid to the level of manifestation of vibrational spectrum and its length. The main purpose of the study was to identify the DNA methylation level by the indicators of the deviation of absorptive waves in $2850 \mathrm{~cm}^{-1}-3050 \mathrm{~cm}^{-1}$ range, corresponding to methyl $\left(-\mathrm{CH}_{3}\right)$ group fluctuations.

The results have shown that the spectrum of methyl group fluctuation was in the range from $2893 \mathrm{~cm}^{-1}$ to $3048 \mathrm{~cm}^{-1}$ and it presented in $92.5 \%$ (37 cases) as one peak, and in $7.5 \%$ (3 cases) there was the splitting of infrared fluctuations of $-\mathrm{CH}_{3}$ groups (Fig. 5). The peak of $-\mathrm{CH}_{3}$ fluctuations was in the range from $2920 \mathrm{~cm}^{-1}$ to $2991 \mathrm{~cm}^{-1}$. Its intensity was in the range from $76.15 \%$ to $98.72 \%$ (average $89.71 \%$ ), it being a strong peak.
Therefore as $-\mathrm{CH}_{3}$ fluctuations is in the range of fluctuations of nitrogenous bases $\left(4000-2000 \mathrm{~cm}^{-1}\right)$, we can assume that the process of pathological methylation takes place in the adenine, guanine and cytosine or thymine additionally adds a methyl group. We found moderate positive correlative relationship between the level of MGMT expression and DNA methylation levels ( $r=$ $0.53, p<0.01)$, between the level of infrared spectrum absorption and level of p53 expression $(r=0.32, p<$ $0.01)$. We observed the tendency of decreasing the expression of ER and PR with the growth of abnormal DNA methylation.

Comparing the results of the chemical composition of IDC tissue with results of immunohistochemical investigations we have got the following results: the growth of HM in neoplastic tissue is accompanied with the increase of HER2/neu $(r=0.36, p<0.05)$, p53 ( $\mathrm{r}=0.53, \mathrm{p}<0.01)$, Ki$67(r=0.47, p<0.01)$, MGMT $(r=0.34, \mathrm{p}<0.05)$ expression and decrease of ER $(r=-0.71, \mathrm{p}<0.01)$ and PR $(r$ $=-0.66, \mathrm{p}<0.01)$ expression. The growth of pathological DNA methylation is also accompanied with the increasing amount of HM in tumor tissue $(r=0.41, \mathrm{p}<0.01)$.

General information concerning the presence of correlation connections between different $\mathrm{BC}$ indicators are presented in Table 3.

It should be noted that all the molecular-genetic indicators of IDC progression authentically increased while reducing of tumor differentiation degree.

\section{Discussion}

Our present is characterized by the growing influence of environmental factors upon human health. Without a

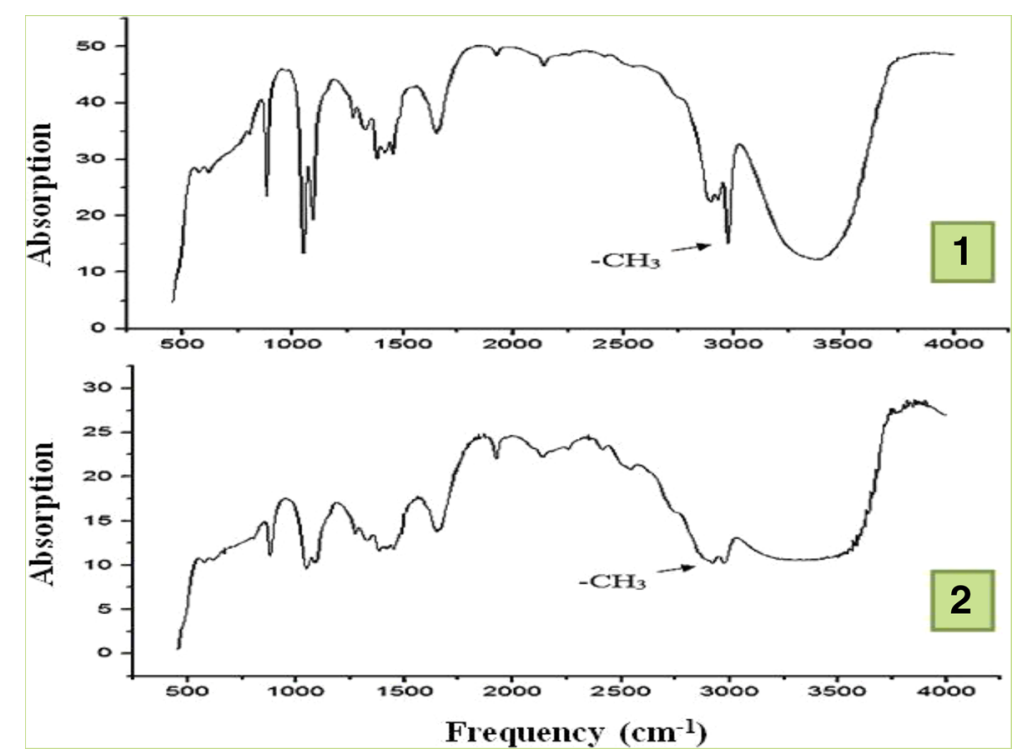

Fig. 5 Infrared spectrum of DNA. $\mathbf{1}$ - spectrum with one peak of methyl group fluctuation, $\mathbf{2}$ - spectrum with the splitting of infrared fluctuations of $-\mathrm{CH} 3$ groups 
Table 3 Factor analysis of IDC indicators

\begin{tabular}{|c|c|c|c|c|c|c|c|c|}
\hline & HM & ER & PR & HER2/neu & Ki-67 & P53 & MGMT & IRS \\
\hline HM & 1 & $-0,71083$ & $-0,65867$ & 0,35888 & 0,46852 & 0,53194 & 0,33878 & 0,41066 \\
\hline ER & $-0,71083$ & 1 & 0,85496 & $-0,56184$ & $-0,3719$ & $-0,28936$ & $-0,50235$ & $-0,30911$ \\
\hline PR & $-0,65867$ & 0,85496 & 1 & $-0,58187$ & $-0,3285$ & $-0,27685$ & $-0,50022$ & $-0,289655$ \\
\hline HER2/neu & 0,35889 & $-0,56184$ & $-0,58187$ & 1 & 0,22818 & 0.22583 & 0,20967 & 0,03736839 \\
\hline Ki-67 & 0,468522 & $-0,3719$ & $-0,3285$ & 0,22818 & 1 & 0,54678 & 0,24542 & 0,17198477 \\
\hline P53 & 0,531949 & $-0,28936$ & $-0,27685$ & 0.22583 & 0,54678 & 1 & 0,20152 & 0,31904601 \\
\hline MGMT & 0,33878 & $-0,50235$ & $-0,50022$ & 0,20967 & 0,24542 & 0,20152 & 1 & 0,5265685 \\
\hline IRS & 0,41066 & $-0,30911$ & $-0,28966$ & 0,03736 & 0,17198 & 0,31904 & 0,52656 & 1 \\
\hline
\end{tabular}

IRS infra red spectrum. Orange color - a negative correlation between HM and ER, HM and PR, ER and HER2/neu, ER and Ki-67, ER and MGMT, PR and HER2/neu, PR and Ki-67, PR and MGMT. Green color - a positive correlation between HM and HER2/neu, HM and Ki-67, HM and P53, HM and MGMT, HM and IRS, P53 and $\mathrm{Ki}-67$, IRS and P53, IRS and MGMT. Blue color - intersection of the same indicators

doubt, $\mathrm{HM}$ are vital micro elements which are included in the vital functions of all body cells. But their function is changing when they arrive in excessive quantities to the intracellular environment, showing their toxic functions. According to the results of spectrophotometry IDC tissue contains in its composition different amount of HM. The reason is that the cancer cells at the expense of disorders of endo-exocytosis of chemicals accumulate $\mathrm{HM}$, in accordance with the growth of their number in the blood vessels (due to the increased receipts of HM to the body). We can explain the increase of heavy elements concentration in the neoplastic tissue with the progression of carcinogenesis at the expense of violation of regulatory mechanisms of $\mathrm{HM}$ assimilation and utilization by tumor cells. Increasing level of cell anaplasia leads to blocking the synthesis of enzymes involved in maintaining of intracellular homeostasis. On the other hand, these microelements stimulate this imbalance by supporting of HM ominous impact on the course of malignancy.

HM accumulation impacts on cell phenotype. This process is realized through a block of steroid receptors that reduces the sensitivity of cancer cells to antihormone therapy. This is due to DNA methylation and increases the amount of MGMT (see below), the initiation of inflammation and inhibition of ESR genes transcription [26], depletion of ER and progression of phenotypic simplification [27].

On the other hand, heavy microelements activate antiapoptotic function and proliferative potential of cells by the synthesis of mt p53 [10]. As shown by our study MGMT protein is no exception. Its quantity grows with increasing $\mathrm{HM}$ intracellular content. We explain the protein growth level through different effects of heavy metals on MGMT synthesis. In our opinion one of the possible points in this chain is their impact on cell DNA. In this case HM might lead to the increment of methyl group accession to the DNA molecule. This fact is not accidental, because the HM are involved in many intracellular processes, including the transfer of electrons and active groups $\left(-\mathrm{CH}_{3},-\mathrm{O},-\mathrm{S}\right)$ [28]. We have found a positive correlative relationship between DNA methylation level and the amount of HM in the tumor tissue during our study.

The general scheme of pathological DNA methylation and MGMT synthesis is as follows (Scheme 1). An exogenous revenue of heavy metal salts into the body leads to their deposition in tumor tissue [29]. On the one hand they block the reparative systems [7], on the other hand they can stimulate the transfer of $-\mathrm{CH}_{3}$ groups [28]. As a result methyl groups are joined to thymine (only thymine $\left(\mathrm{C}_{5} \mathrm{H}_{6} \mathrm{~N}_{2} \mathrm{O}_{2}\right)$ has in its composition in norm $-\mathrm{CH}_{3}$ group) and $-\mathrm{CH} 3$ groups to other nitrogen bases. The excessive abnormal DNA methylation can stimulate the reparative system activation, which is represented by MGMT protein, which permanently removes attached $-\mathrm{CH}_{3}$ group from nitrogenous bases [20].

Inactivated MGMT enters into relationship with receptors for steroid hormones inhibiting their function [21]. This fact is confirmed by the presence of a negative correlative connection between the MGMT expression and steroid receptors. The lack of relationship between the MGMT, p53 and Ki-67 expression indicates separate enzyme impact on the course of the malignant process that does not depend on the presence of other disorders in the pathogenesis [23]. Instead, the level of p53 protein 


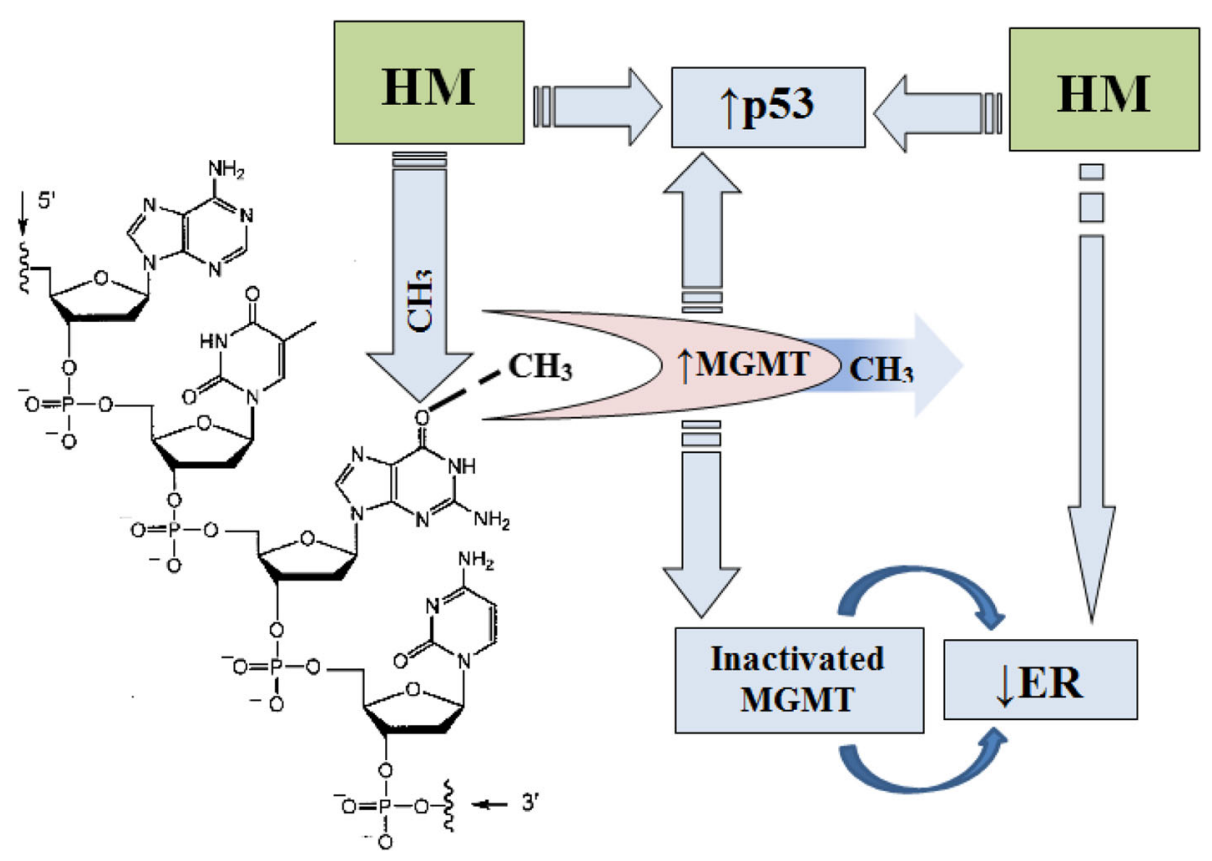

Scheme 1 The pathological DNA methylation and its effect on the receptor profile of tumor tissue

expression increased together with increasing of the level of DNA methylation. This indicates the impact of the methylation on cancer cells pro-apoptotic function [17].

The relationship between the expression of ER and PR, ER and HER2/neu, PR and HER2/neu, p53 and Ki67, ER and Ki-67, PR and Ki-67 indicate the presence of close cooperation between the various links of IDC progression [10, 30].

\section{Conclusions}

Heavy metals are accumulated in breast cancer tissue. The total amount of them range from $51.21 \times 10^{-3}$ to $84.86 \times 10^{-3} \mu \mathrm{g} / \mathrm{kg}$ (average $72.44 \times 10^{-3} \mu \mathrm{g} / \mathrm{kg}$ ) in this tumor. They are accumulated more in the parenchymal component of tumor tissue. We have established the relationship between the heavy metals accumulation in the foci of neoplasia and degree of breast cancer malignancy.

DNA of tumor tissue has a different level of methylation which changes with the amount of heavy metals in cancer cells (a positive correlation between the amount of heavy metals in the neoplastic tissue and DNA methylation level has been established $-r=0.41, p<0.05$ ). This is displayed on the synthesis of prognostically important receptors (MGMT, p53) in neoplastic tissue. Inactivated MGMT can enter into relationship with receptors for steroid hormones inhibiting their function.

The growth of heavy metals in neoplastic tissue is accompanied with the increase of HER2/neu, p53, Ki-67, MGMT expression and decrease of ER and PR expression. The relationship between the expression of ER and
PR, ER and HER2/neu, PR and HER2/neu, p53 and Ki67, ER and Ki-67, PR and Ki-67 indicate the presence of close cooperation between various links of invasive ductal carcinoma progression.

Heavy metals through different pathogenetic links stimulate the progression of breast cancer and reduce its sensitivity to treatment.

\section{Abbreviations}

BC: Breast cancer; ER: Estrogen receptor; HER2/neu: Human epidermal growth factor receptor 2; HM: Heavy metals; IDC: Invasive ductal carcinoma; MGMT: O6-methyguanine-DNA methyltransferase; mt p53: Mutant type p53; PR: Progesterone receptor; wt p53: Wild type p53

\section{Acknowledgements}

We thank Zolotarova Vera who helped in the conduction of immunohistochemical reactions.

\section{Funding}

The work was carried out with the support of the research theme "Development of the diagnosis method of the reproductive systemorgans tumors using cellular adhesion molecules of cancer-embryonic antigen"(state registration number $62.12 .01-01.17 / 20.3 П)$ and an internal grant from the Sumy State University "Protein of heat shock as prognostic markers for malignant tumors development in the reproductive system".

\section{Availability of data and materials}

The main results of histological and immunohistochemical studies presented in figures and text of this article.

\section{Authors' contributions}

All authors agreed to be accountable for all aspects of the work and ensuring accuracy and integrity and approved the final version of this manuscript. ML, AR and VS were responsible for final approval of the article, analysis and interpretation of the data. SR, YL and KS were involved in the writing of the manuscript, participated in writing and editing the manuscript. 


\section{Ethics approval and consent to participate}

Tumor specimens from woman, who had given informed consent, were obtained in Regional Oncology Center, Sumy. This study was approved by the Institutional Review Board at the Sumy State University and was conducted in accordance with the Declaration of Helsinki and International Conference on Harmonization/Good Clinical Practice guidelines.

\section{Consent for publication}

Not applicable.

\section{Competing interests}

The authors declare that they have no competing interests.

\section{Publisher's Note}

Springer Nature remains neutral with regard to jurisdictional claims in published maps and institutional affiliations.

\section{Author details}

'Department of pathology, Sumy State University, st. Privokzalnaya, 31, Sumy Postal code 40022, Ukraine. ${ }^{2}$ Department of normal anatomy, Sumy State University, Sumy, Ukraine. ${ }^{3}$ Cardiology department of Sumy regional hospital, Sumy, Ukraine. ${ }^{4}$ Sumy Regional Clinical Perinatal Center, Sumy, Ukraine.

Received: 18 April 2017 Accepted: 16 November 2017

Published online: 28 November 2017

\section{References}

1. Lakhani SR, Ellis IO, Schnitt SJ, Tan PH, van de Vijver MJ. WHO classification of tumours of the breast. IARC/world health organization classification of tumours. Lyon, France: WHO Press; 2012.

2. Zotov AS, Belik EO. Mastopathy and breast cancer. Moscow: MEDpress-inform; 2005. p. 112

3. Verkooijen HM, Fioretta G, Vlastos G, Morabia A, Schubert H, Sappino AP Pelte MF, Schäfer P, Kurtz J, Bouchardy C. Important increase of invasive lobular breast cancer incidence in Geneva, Switzerland. Int J Cancer. 2003; 104(6):778-81.

4. Parkin DM, Bray F, Ferlay J, Pisani P. Global cancer statistics, 2002. CA Cancer J Clin. 2005;55(2):74-108.

5. Vashkulat NP. Establish levels of heavy metals in soils in Ukraine. Environ Health. 2002;2:44-6.

6. Bont DR, Larebeke NV. Endogenous DNA damage in humans: a review of quantitative data. Mutagenesis. 2004;19(3):169-85.

7. Xi H. Does iron have a role in breast cancer? Lancet Oncol. 2008;9(8):803-7.

8. Taylor KM, Vichova P, Jordan N, Hiscox S, Hendley R, Nicholson RI. ZIP7mediated intracellular zinc transport contributes to aberrant growth factor signaling in antihormone-resistant breast cancer cells. Endocrinology. 2008; 149:4912-20.

9. Lowndes SA, Sheldon HV, Cai S, Taylor JM, Harris AL. Copper chelator ATN224 inhibits endothelial function by multiple mechanisms. Microvasc Res. 2009;77(3):314-26.

10. Romaniuk A, Lyndin M, Moskalenko R, Kuzenko Y, Gladchenko O, Lyndina Y. Pathogenetic mechanisms of heavy metals effect on proapoptotic and proliferative potential of breast cancer. Intervent Med Appl Sci. 2015;7(2):63-7.

11. Geyer FC, Rodrigues DN, Weigelt B, Reis-Filho JS. Molecular classification of estrogen receptor-positive/luminal breast cancers. Adv Anat Pathol. 2012;19: 39-53.

12. Nair BC, Vallabhaneni S, Tekmal RR, Vadlamudi RK. Roscovitine confers tumor suppressive effect on therapy-resistant breast tumor cells. Breast Cancer Res. 2011;13:80-9.

13. Weigel MT, Dowsett M. Current and emerging biomarkers in breast cancer: prognosis and prediction. Endocr Relat Cancer. 2010;17:245-62.

14. Eldar A, Rozenberg H, Diskin-Posner Y, Rohs R, Shakked Z. Structural studies of p53 inactivation by DNA-contact mutations and its rescue by suppressor mutations via alternative protein - DNA interactions. Nucl Acids Res. 2013; 41:1-12.

15. Buck-Koehntop BA, Defossez PA. On how mammalian transcription factors recognize methylated DNA. Epigenetics. 2013;8(2):131-7.

16. Hansen KD, Timp W, Bravo HC, Sabunciyan S, Langmead B, McDonald OG, Wen B, Wu H, Liu Y, Diep D, Briem E, Zhang K, Irizarry RA, Feinberg AP. Increased methylation variation in epigenetic domains across cancer types. Nat Genet. 2011;43(8):768-75.
17. Heyn H, Sayols S, Moutinho C, Vidal E, Sanchez-Mut JV, Stefansson OA, Nadal E, Moran S, Eyfjord JE, Gonzalez-Suarez E, Pujana MA, Esteller M. Linkage of DNA Methylation quantitative trait loci to human cancer risk. Cell Rep. 2014;7(2):331-8.

18. Stefanska B, Huang J, Bhattacharyya B, Suderman M, Hallett M, Han ZG, Szyf M. Definition of the landscape of promoter DNA hypomethylation in liver cancer. Cancer Res. 2011;71(17):5891-903.

19. Jacinto FV, Esteller M. MGMT hypermethylation: a prognostic foe, a predictive friend. DNA Rpair. 2007;6(8):1155-60.

20. Munot K, Bell SM, Lane S, Horgan K, Hanby AM, Speirs V. Pattern of expression of genes linked to epigenetic silencing in human breast cancer. Hum Pathol. 2006;37(8):989-99.

21. Teo AK, Oh HK, Ali RB, Li BF. The modified human DNA repair enzyme O6Methylguanine-DNA Methyltransferase is a negative regulator of Estrogen receptor-mediated transcription upon alkylation DNA damage. Mol Cell Biol. 2001;21(20):7105-14

22. Sharma S, Salehi F, Scheithauer BW, Rotondo F, Syro LV, Kovacs K. Role of MGMT in tumor development, progression, diagnosis, treatment and prognosis. Anticancer Res. 2009;29(10):3759-68.

23. Fumagalli $C$, Pruneri $G$, Possanzini $P$, Manzotti M, Barile M, Feroce I, Colleoni M, Bonanni B, Maisonneuve P, Radice P, Viale G, Barberis M. Methylation of O6-methylguanine-DNA methyltransferase (MGMT) promoter gene in triplenegative breast cancer patients. Breast Cancer Res Treat. 2012;134(1):131-7.

24. Neto JC, Ikoma MM, Carvalho KC, Vassallo J, De Brot M, Gobbi H, Soares FA, Rocha RM. MGMT and PTEN as potential prognostic markers in breast cancer. Exp Mol Pathol. 2012:92(1):20-6.

25. Kuzenko $\mathrm{Y}$. Method: chemical and morphological studying of paraffin sections. Morphologia. 2014;8(2):89-92.

26. Romaniuk A, Lyndin M. Immune microenvironment as a factor of breast cancer progression. Diagn Pathol. 2015;10:79.

27. Romaniuk AM, Lyndin MS, Moskalenko RA, Zolotarova AV. Evaluation of the receptors estrogen, progesterone and her $2 /$ neu expression in the breast cancer tissue under the influence of trace elements on the body. J Clin Exp Med Res. 2014;2(2):168-75

28. Arita A, Costa M. Epigenetics in metal carcinogenesis: nickel, arsenic, chromium and cadmium. Metallomics. 2009;1(3):222-8.

29. Silva MP, Soave DF, Ribeiro-Silva A, Poletti ME. Trace elements as tumor biomarkers and prognostic factors in breast cancer: a study through energy dispersive x-ray fluorescence. BMC Res Notes. 2012;5:194.

30. Davion S, Sullivan M, Rohan S, Siziopikou KP. p53 expression in triple negative breast carcinomas: evidence of age-related and racial differences. Journal of Cancer Therapy. 2012;3:649-54.

\section{Submit your next manuscript to BioMed Central and we will help you at every step:}

- We accept pre-submission inquiries

- Our selector tool helps you to find the most relevant journal

- We provide round the clock customer support

- Convenient online submission

- Thorough peer review

- Inclusion in PubMed and all major indexing services

- Maximum visibility for your research

Submit your manuscript at www.biomedcentral.com/submit
) BioMed Central 